\title{
Motivation and Self-Confidence in Motor Activities in Kindergarten
}

\author{
Tiara Prima Ramdini ${ }^{1, *}$, Yaswinda ${ }^{2}$ \\ ${ }^{1,2}$ Department of Early Childhood Education, Padang State University, Indonesia \\ *Corresponding author. Email: tiaraprimaramdini@gmail.com
}

\begin{abstract}
Early childhood is an active and energetic individual. Children love to do challenging motion activities. Because the movement activities that are routinely carried out by children will have a good impact on their growth and development. There are several factors that influence children's movement. The results showed that routine physical activities given to young children/ can stimulate the growth and development of the body including the brain, increasing the body's resistance to disease. However, children's movement and motor activities begin to decrease due to several things. For example, children spend more time playing gadgets. In addition, research shows that nearly $70 \%$ of three years old children in Europe attend day care services so that they stay more indoors and lead to high rates of obesity. Meanwhile, children who are obese are twice as likely to have bad self-confidence than children who are of normal weight Meanwhile, the results of other studies show that children in coastal areas have better basic motor skills than other areas. It is proven from 8 sub-districts in the city of Padang, only 2 sub-districts in the coastal area show very good results. However, these results are not perfect due to other factors that have not been observed, one of which is motivation and self-confidence. With the existence of further analysis, it is hoped that it can improve the results of previous research and see how motivation and self-confidence of children in carrying out movement activities in Kindergarten in the city of Padang.
\end{abstract}

Keywords: Motivation, confidence, early childhood, movement activities.

\section{INTRODUCTION}

Children who are at the age of 0-6 years and are in a golden period and have the potential to be developed optimally according to the stages and aspects of their development. To develop these potentials, educational institutions are needed to accommodate them. The institution that houses formal education for early age is Kindergarten. In line with the opinion Kindergarten is an early childhood education unit in the formal education pathway that organizes educational programs for children aged four to six years. With the aim of laying the basic foundation. Early childhood has a different character from one another.

Characteristics of early childhood include being curious, egocentric, and active. Therefore, the learning or stimulation provided is learning that can encourage children to actively seek, make choices, express opinions and do and experience themselves. In line with the opinion of Kiram [1] that through various kinds of fun physical activities, children get a positive impact, especially on their growth and development. Through play activities carried out by children, children learn to prepare for their future lives, because through playing children learn how to interact with friends.

Movement/physical activity of children is very important for children. In children, moderate-intensity activity can improve overall health, and help prevent chronic disease in at-risk adolescents. The results of the study from Carson [2] show that regular activity and screen-based sedentary behaviour at least in the early years (birth to 4 years) will produce many benefits in physical, social, emotional, and cognitive development which are the centres of growth and development. healthy development and prevention of chronic diseases.

Meanwhile, the results of research Paiman [3] show that physical activity can improve physical fitness and the quality of children's organs, including the heart, lungs, blood circulation, energy metabolism, growth hormone, immune system, and secretion system. Meanwhile, physical activity is closely related to children's gross motor skills. According to Sujiono [4], the basic competencies of gross motor skills of kindergarten children that are expected to be developed by the teacher when the child enters the preschool institution is that the 
child is able to carry out coordinated physical activities in the context of flexibility and preparation for balance, agility, and to train courage.

Kindergarten children's physical activity can be in the form of motor activity and is closely related to motivation and self-confidence. Based on the research results from Manzilatur [5], the factors that influence children's gross motoric development are environmental factors. These factors affect the development of motor skills, motivation to move, because of stimulation from the environment. On the other hand, the lack of movement to perform active movements will slow down the child's motor development.

Another link between motivation, self-confidence and movement activities is found in physical literacy. Physical literacy is an important literacy to be developed. Developed countries have launched Physical Literacy earlier than Indonesia. Physical literacy (PL) is the ability to move, trust in one's ability, adopt a healthy lifestyle by adopting an active lifestyle, and have good basic movement skills. In the context of early childhood education. This becomes a special urgency for the child's motivation and self-confidence. This is also strengthened based on research reports and Canadian statistics showing that childhood obesity can cause psychological problems, especially for children aged less than 10 years. In a study of Anggraeni [6] states that children will be twice as likely to have a bad self-confidence/self-image compared to children who have normal weight.

In other studies, it was revealed that obesity also affects children's motivation and self-confidence. Even the detrimental social consequences of childhood and adolescence obesity may have long-term negative effects on self-esteem, body image and economic mobility. Meanwhile, based on research from Murata [7], shows that moving efficiently which is formed from basic movements will make children more confident and have good skills in their active participation. Apart from motivation, another factor that needs to be developed if the child is achieving is self-confidence.

Another thing that causes a decrease in children's motivation and self-confidence to do physical activity is the excessive use of gadgets that starts at an early age. Almost all activities carried out by humans are related to the digital world. Starting from parents, adolescents, to children who are familiar with gadgets. There are many reasons someone uses gadgets, for example, they want to get information quickly. In line with the results from Maya [8] that parents generally provide gadgets to children so that children can read and count quickly and so that they are smart quickly, gadgets are also given so that children do not leave the house. This makes the physical activity he does less minimal because there is no more motivation and confidence from within himself to do more physical activity.
In addition to some of the research above based on the results of research from Mardela [9] which shows that the basic movement abilities of children in coastal areas are better than children in mountainous areas, it is proven that the results of the basic movement abilities of children in North Padang District, namely TK Kartika I, movement skills The basic students are 2 people in the Medium category, 3 people in the Good category, and 4 people in the Very Good category, while the movement skills of children at TK Pertiwi I, West Padang District in general are 5 people in the moderate category, 1 person in the good category, and 2 people. people in the very kind category.

Of the 8 sub-districts studied, there were only 2 subdistricts that had an average basic mobility in the very good and very good categories, and there were no children with poor abilities. The research also does not describe the child's basic motor skills as a whole because there are still many other indicators that are still neglected, such as children's motivation, physical disability, and environmental conditions.

From some of the research results above, it can be concluded that children's motivation and self-confidence are important and affect children's movement activities. However, data regarding the constraints faced by movement activities, factors that influence motivation and self-confidence as well as how much motivation and self-confidence of children in carrying out movement activities in Padang City have not been found.

\section{THEORETICAL REVIEW}

\subsection{Definition of Motivation}

The main theory (grand theory) which is used as the basis of this theory is Maslow's theory of motivation. According to Maslow [10] a person behaves or works because of the urge to meet various needs. The needs a person wants are tiered, meaning that if the first need has been met, then the second level needs will become the main one. Furthermore, if the needs of the second level have been met, then the needs of the third level emerge and thereafter up to the fifth level of needs. One of the needs that must be met is physical needs, security, a sense of belonging, respect from others, and self-actualization. Meanwhile, according to Ormrod [11] motivation is something that enlivens, directs and maintains behaviour.

Motivate learners to move, putting them in a certain direction and keeping them moving. It is also in line with the opinion from Uno [12], that motivation is a basic impetus that can move someone to behave. Meanwhile, according to Winkel [13] reveals that motivation is a motive that becomes active when someone conducts an experiment. A similar opinion was also expressed by Soemanto [14] that motivation is defined as a change in energy marked by effective encouragement and reactions 
to achieving goals. It is also stated that the change in energy that gives strength to the behaviour to achieve goals has occurred in a person.

From some of the definitions of motivation above, it can be concluded that motivation is a change in energy or a driving force from within a person that influences a person to behave or work, marked by an impulse that is able to turn on, move and maintain the behaviour of a person who will be active when conducting an experiment to achieve a goal.

\subsection{Types of Motivation}

Motivation can be grouped by type. According to Djamarah [15] motivation is divided into two types, namely intrinsic motivation and extrinsic motivation. Intrinsic motivation is that the motives for functioning do not need to be stimulated from outside, meaning that this motivation can be active itself due to the impulse that has been owned from within itself to do something. This intrinsic motivation comes from the heart which is generally due to one's awareness. Kindergarten children show this motivation, for example, when the child wants to sing alone without being asked, because he already has his own interest or desire to sing. This arises because of interest or curiosity (curiosity) towards these activities so that motivation appears in him. Extrinsic motivation is active motives due to stimulants or the influence of other people so that they do something.

Meanwhile, according to Ormrod [11] that extrinsic motivation is motivation that is caused by individual external factors and is not related to the task at hand. Meanwhile, intrinsic motivation is motivation that is caused by factors within or inherent in the task at hand. While a slightly different opinion is expressed by Woodworth [16] that there are three groups of motives, namely (a) organic needs, which means motives related to the internal needs of the body such as hunger, thirst, needs, movement. , resting or sleeping, and others, (b) the motives that arise suddenly (energy motives) are motives that arise not because of the will of the individual but because there are external stimuli, for example the motive to escape from danger, the motive to try to overcome an obstacle, and (c) objective motives, namely motives directed or directed at a particular object or purpose around us, arising from an impulse from within us.

From the above opinion it can be concluded that there are two types of motivation, namely intrinsic motivation and extrinsic motivation. Intrinsic motivation is a motive or impulse that comes from existing factors within a person and the functioning of this motive need not be stimulated from the outside. Meanwhile, extrinsic motivation is active motives that require stimulation or influence from others or are caused by factors from outside the individual himself so that he does something.

\subsection{Motivational of Elements}

The elements contained in motivation are various. Many opinions mention the elements contained in this motivation. As stated by Sardiman [17] that motivation contains three important elements, namely: 1) motivation initiates a change in energy in every human being. The development of motivation will bring about several energy changes in the neurophysiological systems that exist in the human organism. The appearance will involve human physical activities, 2) motivation is characterized by emergence, a feeling of "feeling", a person's affection, 3) motivation will be stimulated because of a purpose. So motivation in this case is actually a response to an action, namely the goal. It is said that motivation does arise from within humans but it emerges because it is stimulated or driven by another element in the form of a goal. Other opinions regarding the driving elements of motivation were conveyed by Sagir [18], the driving elements of motivation, including: a) performance (achievement), b) recognition, c) challenge, d) responsibility, e) development, f) involvement, g) opportunity.

From some of the opinions above, it can be concluded that motivation contains 3 elements or components, namely moving, directing and supporting human behaviour, while the elements that can drive motivation include performance, rewards, challenges and responsibilities, development, involvement, and opportunities, namely moving, directs, and supports human behaviour.

\subsection{Function of Motivation}

According to Notoatmodjo [19] that motivation has three functions, namely: a) encouraging humans to act as a driving force or a motor that releases energy, b) determining the direction of action, namely towards the goal to be achieved. This means that motivation can provide direction and activities that must be carried out in accordance with the formulation of pre-planned goals, c) selecting actions, namely determining what actions must be done in harmony in order to achieve, by setting aside actions that are not useful for that goal. The same thing was also expressed by Sardiman [17] that apart from functioning as a driving force for business and achievement, motivation also functions, namely: a) encouraging students to act, becoming a driving force or motor that releases energy, b) determining the direction of action, namely towards the goals that have been achieved, c) selecting actions, namely determining the actions to be performed that can achieve the goal by setting aside actions that are not useful for that goal.

Meanwhile, according to Dayana [20] that with motivation someone can shine and succeed in living his life. A person's life goals or goals can be achieved if they have a strong motivation within them. Another opinion was also expressed by Dimyati \& Mujiyono [21] on the 
importance of learning motivation for students, namely: 1) awareness of the position at the beginning of learning, the process and the final result, 2) informing about the strength of learning efforts, which are compared to peers, 3) directing activities learning, 4) encouraging the enthusiasm for learning, 5) making the awareness that there is a continuous learning journey and then work.

Based on some of the opinions above, it can be concluded that motivation functions to encourage people to act, determine the direction of action, select actions, awaken the initial position a) encourage humans to act, as a driving force or motor that releases energy, b) determine the direction of action, namely towards the goal to be achieved. This means that motivation can provide direction and activities that must be carried out in accordance with the formulation of pre-planned goals, c) selecting actions, namely determining what actions must be done in harmony in order to achieve, by setting aside actions that are not useful for that goal.

\subsection{Factors Affecting Motivation}

The success of someone in the process of obtaining something is influenced by existing motivations both from within himself and from his wild. The factors that influence motivation also vary. Some come from within and from outside the individual. In line with the opinion

In line with this, the factors that influence learning motivation according to Saefullah [22] are 1) aspirations, 2) learning ability, 3) student conditions, 4) environmental conditions, 5) the elements of dynamics in learning, 6) the teacher's efforts to teach students. Whereas Kompri [23] states that the factors that affect student learning motivation are 1) the aspirations of students, 2) students' abilities, 3) student conditions, 4) student environmental conditions.

From some of the opinions above, it can be concluded that the factors that influence motivation are internal (from within the individual) and external (from outside the individual). Factors that can lead to external motivation consist of individual perceptions of themselves, self-esteem and achievements, expectations. Meanwhile, the internal motivational factors are a) the need, b) the knowledge of one's own progress, and c) the existence of ideals or aspirations.

\subsection{Characteristic of Motivation}

A person who has inner motivation can be seen from the characteristics that arise from within him. According to Sardiman [17] that the motivation that exists in a person has the following characteristics: 1) diligent in facing tasks (can work continuously for a long time, never stop before completion), 2) resilient in facing difficulties (no quick to give up), 3) has a future orientation, 4) shows an interest in various problems (interest in success), 5. preferably works independently, 6) quickly gets bored of routine tasks (things that are mechanical, repetitive, so less creative), 7) can defend his opinion (if you are sure of something), 8) never easily let go of what is already believed, 9) enjoy looking for and solving problems.

\subsection{Definition of Self-confidence}

The main theory (grand theory) used on the selfconfidence variable here is Bandura's theory. According to the theory of Bandura [24] self-confidence is a belief that a person has that he is able to behave as needed to get the results as expected. Meanwhile, according to Blegur [25] self-confidence is one of the personality traits that combines thoughts and feelings, struggles and hopes, fears and fantasies, or individual attitudes related to their abilities. Meanwhile, according to Blake [26] defines self-confidence as a person's willingness to try something that is the most frightening to a person and that person believes that he is able to manage something that arises. Self-confidence is not a trait that is inherited (innate) but is obtained from life experience, and can be taught and instilled through education, so that certain efforts can be made to form and increase self-confidence. Furthermore, confidence in general is an important part of a person's personality characteristics that can facilitate one's life

From some of the opinions above, it can be concluded that self-confidence is a term that shows a person's attitude or belief/self-will towards one's own abilities and the courage to do something new to become psychological independence in directing thoughts and exerting energy based on his own abilities and being an important part of personality characteristics of a person who can facilitate his life.

\subsection{Personal Characteristics of Confidence}

The characteristics of self-confidence will be more obvious if a person looks directly at the events experienced by himself or others. Based on various events or experiences, it can be seen the symptoms of a person's behaviour that describe the presence of selfconfidence or not. Some of the characteristics or characteristics of individuals who have proportional selfconfidence are as follows: 1) believe in one's abilities or competencies, so that they do not need praise, recognition, acceptance or respect from others, 2) not motivated to show conformist attitudes in order to be accepted by other people or groups, 3) dare to accept and face other people's rejection, dare to be yourself, 4) have good self-control (not moody and emotionally stable)., 5) having an internal locus of control (seeing success or failure, depending on one's own efforts and not easily giving up on fate or circumstances and not echoing or expecting help from others), 6) having a positive perspective on self, others and situation outside of him, 
7) having realistic expectations of oneself, so that when those hopes are realized, he is still able to see the positive side of himself and the situation that occurs.

Meanwhile, according to Blake [26] personal characteristics with high self-confidence are: 1) believing in one's abilities, 2) being independent in making decisions, 3) having a positive sense of yourself, 4) daring to try, 5) internalizing actions. Characteristics of people who have self-confidence are people who believe in their abilities, can place themselves according to the circumstances in which they are, have a positive perspective on themselves, are aware that everyone has weaknesses and strengths.

From some of the opinions above, it can be concluded that the characteristics of self-confidence of people who believe in their abilities, can place themselves according to the situation in which they are, have a positive perspective on themselves, realize that everyone has weaknesses and strengths.

\subsection{Definition of Motion}

Motion refers to something that can be observed in changes in the location of several parts of the body. Movement is the ultimate action that forms the basis of motor processes. Motion is the process of moving a place from the initial position to the final position. If an object or living thing shifts its position from its initial position, it is said that the object has moved. In line with the opinion from Kiram [1] movement for humans is something that is important and inherent in humans themselves, both motions to achieve something, solve problems, and movements made in communicating.

From some of the opinions above, it can be concluded that motion is something that can be observed in the change in the location of several parts of the body from start to finish and is something that is important for humans themselves to achieve something, solve problems, and move in communicating.

\subsection{Definition of Physical Activity}

Movement or physical activity is the main activity for early childhood. Physical activity becomes all body movements produced by contraction of skeletal muscles and substantially increases energy expenditure. Early childhood do their movement activities through playing and children will do play activities in the form of motion.

Physical activity is physical movement carried out by the body's muscles and their supporting systems. Physical activity is every movement of the body due to activity of the skeletal muscles which results in energy expenditure. Everyone does physical activity from one individual to another depending on the individual's lifestyle and other factors. Physical activity consists of activities during work, sleep and leisure time.
From some of the opinions above, it can be concluded that early age children carry out their movement activities through play and children will do play activities in the form of motion, while physical activity/movement is physical movement performed by the muscles of the body and its supporting system. Everyone does physical activity from one individual to another depending on the individual's lifestyle and other factors.

\subsection{Benefits of Physical Activity/Movement}

Increasing physical activity and limiting sedentary behaviour, such as watching $\mathrm{TV}$, have a good relationship with cognitive and academic performance. In addition, there are several advantages of being a child who lives an active life, namely: 1) movement is an important part of the child's physical, mental, and emotional development, 2) fulfilment of children's curiosity satisfaction in motion, 3) feeling happy when teachers, parents, and families are involved in physical activity and play, 4) physical activity can make children feel good about themselves, 5) in games or activities children interact with each other to develop social games, 6) activities develop positively towards behaviour through activities physical, 7) children solve problems and achieve success through challenges and exploration.

Based on some of the opinions above, it can be concluded that by doing physical activity/movement it can be concluded that by doing physical or physical activity it will help children's cognitive development and academic abilities, help with physical, mental, emotional development and solve problems and achieve success through challenges and exploration.

\section{CONCLUSION}

Motivation is a change in energy or a driving force from within a person that influences a person to behave or work, marked by an impulse that is able to turn on, move and maintain the behaviour of a person who will be active when conducting an experiment to achieve a goal The factors that influence motivation are internal (from within the individual) and external (from outside the individual). Factors that can lead to external motivation consist of individual perceptions of themselves, selfesteem and achievements, expectations. Meanwhile, the internal motivational factors are a) the need, b) the knowledge of one's own progress, and c) the existence of ideals or aspirations.

Self-confidence is a term that shows a person's attitude or belief/self-will towards one's own abilities and the courage to do something new to become psychological independence in directing thoughts and exerting energy based on his own abilities and being an important part of personality characteristics of a person who can facilitate his life. The characteristics of selfconfidence will be more obvious if a person looks 
directly at the events experienced by himself or others. Based on various events or experiences, it can be seen the symptoms of a person's behaviour that describe the presence of self-confidence or not. Some of the characteristics or characteristics of individuals who have proportional self-confidence are as follows: 1) believe in one's abilities or competencies, so that they do not need praise, recognition, acceptance or respect from others, 2) Not motivated to show conformist attitudes in order to be accepted by other people or groups, 3 ) dare to accept and face other people's rejection, dare to be yourself, 4) have good self-control (not moody and emotionally stable), 5) having an internal locus of control (seeing success or failure, depending on one's own efforts and not easily giving up on fate or circumstances and not echoing or expecting help from others, 6) having a positive perspective on self, others and situation outside of him, 7) having realistic expectations of oneself, so that when those hopes are realized, he is still able to see the positive side of himself and the situation that occurs.

The early childhood carries out their movement activities through play and children will do play activities in the form of motion, while physical activity movement is physical movement performed by the muscles of the body and its supporting system. Everyone does physical activity from one individual to another depending on the individual's lifestyle and other factors. Motion is something that can be observed in the change in the location of several parts of the body from start to finish and is something that is important for humans themselves to achieve something, solve problems, and move in communicating.

That by doing physical activity/movement it can be concluded that by doing physical or physical activity it will help children's cognitive development and academic abilities, help with physical, mental, emotional development and solve problems and achieve success through challenges and exploration.

\section{AUTHORS' CONTRIBUTIONS}

The authors who contributed to this article were Tiara Prima Ramdini and Yaswinda. This article can be a reference for researchers who are investigating the motivation and confidence aspect in motor activities at kindergarten.

\section{ACKNOWLEDGMENTS}

Thanks to DRPM, Kemenristekdikti, BRIN for funding this article and LP2M UNP for facilitating the writing of this article.

\section{REFERENCES}

[1] Kiram, Y. Belajar keterampilan gerak. Jakarta: Prenada Media Group; 2019.
[2] Carson V, Hesketh KD, Rhodes RE, Rinaldi C, Rodgers W, Spence JC. Psychometric properties of a parental questionnaire for assessing correlates of toddlers' physical activity and sedentary behaviour. Measurement in Physical Education and Exercise Science. 2017;21(4):190-200. Available from: https://doi.org/10.1080/1091367X.2017.1322087.

[3] Paiman P. Olahraga dan kebugaran jasmani (Physical fitness) pada anak usia dini. Cakrawala Pendidikan [Internet]. 2009;3(3):270-281. Available from: https://doi.org/10.21831/cp.v3i3.04.

[4] Sujiono B. Metode pengembangan fisik. Jakarta: Universitas Terbuka; 2015.

[5] Manzilatur RA, Astini SM. Peran kegiatan tari untuk mengembangkan kemampuan motorik kasar anak kelompok B di TK Muslimat Mazraatul Ulum II Paciran Lamongan. PAUD Teratai. 2013; 2(1):1-7.

[6] Anggraeni N. Belajar dari induk gajah. Jakarta: PT. Elex Media Komputindo; 2012.

[7] Murata NM, Maeda JK. Structured play for preschoolers with developmental delays. Early Childhood Education Journal. 2002;29(4):240-6.

[8] Maya FR. Hubungan intensitas pemanfaatan gadget dengan prestasi belajar siswa kelas V Sekolah Dasar. Jurnal Pemikiran dan Pengembangan Sekolah Dasar. 2017;5(2):722-73.

[9] Mardela R. Keterampilan gerak dasar siswa PAUD Kota Padang. Jurnal Performa Olahraga. 2016;1(2):206-22. Available from: https:// 10.24036/jpo87019.

[10] Maslow, HA. Motivasi dan kepribadian. Teori motivasi dengan pendekatan hierarki kebutuhan manusia. Jakarta: Pustaka Binaman Pressindo; 1993.

[11] Ormrod JE. Psikologi pendidikan membantu siswa tumbuh dan berkembang. Jakarta: Erlangga; 2009.

[12] Uno HB. Teori motivasi dan pengukurannya. Jakarta: Bumi Aksara; 2014.

[13] Winkel WS. Psikologi pengajaran. Jakarta: Grasindo; 2014.

[14] Soemanto, W. Psikologi pendidikan. Jakarta: Rineka Cipta; 2012.

[15]Djamarah SB. Psikologi belajar. Jakarta: Rineka Cipta; 2011.

[16] Woodworth RS, Marquis D. Psychology: A study of mental life psychology revivals. London: Taylor \& Francis Group; 2015.

[17] Sardiman A. Interaksi dan motivasi belajar mengajar. Jakarta: Rajawali Press; 2011.

[18] Sagir S. Motivasi dan disiplin kerja karyawan untuk peningkatan produktivitas dan produksi. Seri produktivitas dan tenaga kerja indonesia. Jakarta: LSUP; 1985. 
[19] Notoatmodjo S. Pendidikan dan perilaku kesehatan. Jakarta: Rineka Cipta; 2003.

[20]Dayana I, Marbun J. Motivasi kehidupan menjalani proses kehidupan untuk kualitas hidup yang lebih baik. Jakarta: Guepedia; 2018.

[21]Dimyati M, Mudjiono. Belajar dan pembelajaran. Jakarta: Rineka Cipta; 2013.

[22] Saefullah US. Psikologi perkembangan dan pendidikan. Bandung: Pustaka Setia; 2012.

[23] Subekti I. Persepsi orang tua terhadap kesiapan sekolah (school readiness) anak usia 5-6 tahun [Doctoral Dissertation, Universitas Negeri Jakarta]. Jakarta: UNJ; 2016.

[24] Fatimah S, Nurhadi, Liestyasari SI. Motif 'agar' dan motif 'karena dalam keputusan orang tua memilih lembaga bimbingan belajar. Jurnal Ilmiah Pendidikan Sosial Antropologi. 2015;5(2):1-15.

[25]Lestari MI. Persepsi orang tua terhadap pentingnya calistung untuk anak usia 5-6 tahun di TK Kartika IX-35 Jember [Bachelor Thesis, Universitas Jember]. Jember; 2019.

[26] Somantri S. Psikologi anak luar biasa. Bandung: PT Refika Aditama; 1976. 